\title{
Karakteristik dan Aktivitas Antioksidan Velva Bayam Merah dan Penstabil CMC (Carboxyl Metyl Cellulose)
}

\author{
Vritta Amroini Wahyudi ${ }^{1}$, Winda Cancerina Harsono Putri ${ }^{2}$, Elfi Anis Saati ${ }^{*}$ \\ ${ }^{1}$ Prodi Teknologi Pangan, Fakultas Pertanian Peternakan, Universitas Muhammadiyah Malang, \\ Malang, Indonesia \\ *Corresponding author email: elfiumm@yahoo.co.id
}

\begin{abstract}
Red spinach is known as a food stuff for protein, vitamins $A, B$, and $C$ and contains mineral salts. Red spinach is used as a natural dye because it is thought that red spinach has betacyanin and anthocyanin content that can produce a purpleish red color. Efforts to increase vegetable consumption are carried out by modifying as a velva, a frozen beverage product that are almost the same as low-fat ice cream Velva. The purpose of this study is to know the interaction of the addition of red spinach extract and CMC stabilizing material, to know the influence of red spinach concentration, and to know the influence of differences in cmc concentrations on Velva characteristics. The implementation of the experiment used a Randomized Group Design (RAK) that was factorially arranged consisting of 2 factors. Factor 1 is the concentration of red spinach extract consisting of 3 levels namely 20\%, 25\%, and 30\% while factor 2 is CMC concentration consisting of 3 levels which is $0.5 \%, 0.75 \%$, and $1 \%$. Observation parameters include vitamin $C$ levels, melting power, viscosity, antioxidants, anthocyanins, and organoleptics that include color, aroma, taste, texture, and fondness. The results showed that red spinach extract had a significant effect on antioxidants with the greatest value in B3 treatment (Spinach Extract 30\%) 53.70\%; vitamin $C$ with the greatest value in B3 treatment (CMC 1\%) $6.3 \mathrm{~g} / \mathrm{mL}$, and anthocyanins with the best 3 treatments are $B 3$ at $1.1675 \mathrm{~mL} / \mathrm{L}$, while CMC has a significant effect on melting power, viscosity, and vitamin $C$ Velva spinach red. The results showed that red spinach Velva contains a small amount of glycine so that the pigment contained is betacyanin
\end{abstract}

Keywords: anthocyanin, betacyanin, CMC (Carboxy Metyl Cellulose), red spinach, velva

\section{PENDAHULUAN}

Velva merupakan makanan pencuci mulut yang berbahan dasar jus buah, air, gula, pewarna, asam sitrat, dan bahan penstabil (Kartika Dewi, 2012). Velva disukai anak-anak hingga dewasa karena rasanya yang manis dan warna yang menarik. Warna yang beraneka ragam menjadi salah satu daya tarik konsumen untuk membelinya. Salah satu pigmen alami yang digunakan yaitu warna merah dari bayam merah. Bayam merah termasuk salah satu jenis bayam yang ada di Indonesia. Bayam merah adalah salah satu spesies bayam yang dapat dimanfaatkan sebagai tanaman obat. Bayam merah dikenal sebagai tanaman hias, namun seiring perkembangan jaman bayam di kenal sebagai bahan pangan sumber protein, vitamin A, B, dan C serta mengandung garam-garam mineral 
seperti kalsium, fosfor, dan besi (Nirmalayanti, 2017). Bayam merah dimanfaatkan sebagai bahan pewarna alami karena bayam merah diduga memiliki kandungan betasianin dan antosianin yang dapat menghasilkan warna merah keunguan (Putri, 2020, Pebrianti et al., 2015).

Salah satu komponen penting dalam pembuatan Velva yaitu bahan penstabil. Bahan penstabil berfungsi untuk menghasilkan tekstur Velva yang lembut, mengurangi pembentukan kristal es yang kasar, dan memberikan daya tahan yang baik terhadap proses pelelehan. Velva bertekstur ideal jika tekstur lembut, dan tidak cepat meleleh (Maria and Zubaidah, 2014). Tujuan penelitian ini adalah untuk mengetahui interaksi dan pengaruh konsentrasi sari bayam dan bahan penstabil CMC terhadap karakteristik Velva.

\section{METODE PENELITIAN \\ Alat dan Bahan}

Alat-alat yang digunakan untuk penelitian, antara lain: Alat yang digunakan pada penelitian ini antara lain sendok, pisau, panci, toples, baskom, blender, timbangan digital, freezer, dan kompor. Alat yang digunakan untuk analisa antara lain termometer, tabung reaksi, rak tabung reaksi, gelas ukur 25 $\mathrm{ml}$, gelas ukur $100 \mathrm{ml}$, gelas ukur $50 \mathrm{ml}$, erlenmeyer $50 \mathrm{ml}$, pipet volume, bola hisap, kuvet, alumunium foil, kertas saring, kain saring, stopwatch, timbangan analitik, viskometer brookfield, sprektrofotometer, $\mathrm{pH}$ meter, sentrifius, dan Ice Cream Maker (ICM).

Bahan yang digunakan dalam pembuatan Velva adalah bayam merah yang diperoleh dari pasar Karangploso dengan umur panen seragam yaitu 25 hari dan tingkat kesegaran 80\%, gula, dan CMC (Carboxy Methyl Cellulose) yang diperoleh dari toko kimia kota Malang. Bahan-bahan kimia untuk analisa seperti iodium, amilum, serbuk DPPH (2,2 dyphenyl-1-picrylhydrazyl), metanol, etanol, larutan $\mathrm{KCl}$, larutan $\mathrm{Na}$-asetat, dan $\mathrm{HCl} 37 \%$.

\section{Metode Penelitian}

Rancangan percobaan dalam penelitian ini adalah Rancangan Acak Kelompok (RAK) yang terdiri dari 2 faktor, yakni faktor 1 perbedaan konsentrasi sari bayam merah (B), terdiri dari 3 taraf, yaitu 20\% (B1), 25\% (B2), dan 30\% (B3) sedangkan faktor 2 konsentrasi CMC terdiri dari 3 taraf, yaitu 0,5\% (K1), $0,75 \%$ (K2), dan 1\% (K3). Penelitian ini diulang sebanyak 2 kali, sehingga total terdapat 9 unit percobaan dan kontrol yaitu produk pasar shorbet stoberi dikarenakan mempunyai warna yang sama yakni merah keunguan. Variabel percobaan dalam penelitian ini, meliputi variabel bebas (konsentrasi sari bayam merah, dan CMC), sedangkan variabel terikat (vitamin C, aktivitas antioksidan, antosianin, daya leleh, viskositas, dan organoleptik).

\section{Pelaksanaan Penelitian}

Bayam merah yang diperoleh dari pasar Karangploso disortasi dan dipotong, kemudian ditimbang dan di steaming pada suhu $80^{\circ} \mathrm{C}$ dengan waktu 2 menit. Proses ekstraksi pigmen yaitu penghancuran bahan dan pelarut dengan perbandingan 2:1 menggunakan blender dengan waktu \pm 1 menit. Filtrat yang 
dihasilkan disaring menggunakan penyaring untuk memisahkan filtrat dan ampas bayam merah akibat hasil penghancuran. Sari bayam merah ditambahkan pada pembuatan Velva sesuai dengan formulasi yang sudah ditentukan sesuai perlakuan. Tahap selanjutnya yaitu pembuatan Velva bayam merah dengan bahan antara lain air sebanyak $200 \mathrm{ml}$, CMC sesuai dengan perlakuan, dan gula $20 \%$. Air $200 \mathrm{ml}$, CMC, dan gula dipasteurisasi dengan suhu $80^{\circ} \mathrm{C}$ selama 2 menit. Setelah adonan dipasteurisasi, kemudian dinginkan adonan hingga $45^{\circ} \mathrm{C}$ lalu homogenkan dengan mixer selama 5 menit.

\section{Prosedur Analisis}

Analisis pada penelitian ini, meliputi: viskositas (Yuwono dkk, 2001), aktivitas antioksidan (Blois, 1958 dalam Hanani et al., 2005), daya leleh (Nelson and Trout, 1965), vitamin C (Obirinakem, 2015), antosianin metode (AOAC, 2005), dan Organoleptik (Rahayu, 2001) meliputi warna, aroma, rasa, tekstur, dan kesukaan.

\section{Pengolahan Data Penelitian}

Data pengamatan penelitian ini dianalisis menggunakan analisa ragam atau analysis of variance (ANOVA) pada taraf 5\% untuk mengetahui pengaruh dari perlakuan selanjutnya apabila perlakuan berpengaruh nyata maka akan dilanjutkan dengan uji DMRT. Penentuan perlakuan terbaik dianalisa menggunakan metode uji de garmo.

\section{HASIL DAN PEMBAHASAN Analisa Bahan Baku}

Analisa dilakukan setelah pembuatan sari bayam dengan metode maserasi menggunakan aquades selama 24 jam. Analisa bahan baku ini meliputi $\mathrm{pH}$, antioksidan, dan vitamin C. Hasil analisa bahan baku sari bayam merah dapat dilihat pada tabel berikut:

Tabel 1. Hasil Analisa Bahan Baku Pigmen

\begin{tabular}{lll}
\hline Karakteristik & Hasil Penelitian & Literatur \\
\hline Vitamin C (mg/100g) & 7,4 & 2,47 (Saati, 2016) \\
Antioksidan (\%) & 69,59 & 58,69 \\
& & (Susilawati et al., 2018) \\
pH & 6,844 & $6-7$ (Pebrianti et al., 2015) \\
\hline
\end{tabular}

Berdasarkan hasil analisa pada tabel diatas untuk bahan baku pigmen bayam merah menunjukkan bahwa komposisi kimia pada bayam merah yang digunakan memiliki kandungan vitamin $\mathrm{C}$ sebesar 7,4 mg/100g sedangkan kadar vitamin C bayam merah yaitu $2,47 \mathrm{mg} / 100 \mathrm{~g}$ (Saati, 2016). Antioksidan ekstrak bayam merah yaitu 69,59 \% sedangkan menurut Susilawatii et el. (2018) sebesar $58,69 \%$. Hasil penelitian berbeda dikarenakan perbedaan jenis bayam merah, dan metode yang digunakan. Hasil analisa $\mathrm{pH}$ ekstrak bayam menunjukkan pada 6,844 sesuai dengan literatur yaitu antara 6-7 (Pebrianti et al., 2015)(Katja, 2019). Pembuatan ekstrak bayam merah dilakukan dengan ekstraksi metode 
maserasi dengan pelarut aquades. Hal ini dikarenakan sifat antosianin yaitu larut dalam air sehingga memakai pelarut polar (like dissolve like).

\section{Vitamin C}

Hasil analisa ragam menunjukkan tidak ada interaksi antara perlakuan penambahan konsentrasi bayam dan CMC terhadap vitamin C Velva. Perlakuan penambahan sari bayam merah dan konsentrasi CMC berpengaruh nyata terhadap vitamin $\mathrm{C}$.

Tabel 2. Nilai Vitamin C Velva dengan Penambahan Ekstrak Bayam Merah

\begin{tabular}{ll}
\hline Perlakuan & Vitamin C $(\mathrm{mg} / 100 \mathrm{~g})$ \\
\hline B1 (Sari Bayam 20\%) & $4,7^{\mathrm{a}}$ \\
B2 (Sari Bayam 25\%) & $5,3^{\mathrm{a}}$ \\
B3 (Sari Bayam 30\%) & $6,3^{\mathrm{b}}$ \\
\hline Kontrol (Produk Pasar) & 9,3 \\
\hline \multicolumn{2}{|c|}{ Keterangan : Angka-angka yang diikuti oleh huruf kecil yang berbeda menunjukkan berbeda } \\
nyata berdasarkan uji DMRT $(\mathrm{a}=5 \%)$
\end{tabular}

Berdasarkan tabel diatas nilai terendah yaitu pada B1 dengan penambahan sari $20 \%$ sebesar $4,7 \mathrm{mg}$ sedangkan nilai tertinggi yaitu pada B3 dengan penambahan sari $30 \%$ sebesar $6,3 \mathrm{mg}$ hal ini disebabkan oleh semakin banyak konsentrasi bayam yang ditambahkan maka semakin tinggi pula nilai vitamin C Velva (Katja, 2019).

Tabel 3. Nilai Vitamin C Velva Bayam Merah dengan Penambahan CMC

\begin{tabular}{ll}
\hline Perlakuan & Vitamin C (mg/100g) \\
\hline K1 (CMC 0,5\%) & $5,0^{\mathrm{a}}$ \\
K2 (CMC 0,75\%) & $5,4^{\mathrm{ab}}$ \\
K3 (CMC 1\%) & $5,9^{\mathrm{c}}$ \\
\hline Kontrol (Produk Pasar) & 9,3 \\
\hline
\end{tabular}

Keterangan : Angka-angka yang diikuti oleh huruf kecil yang berbeda menunjukkan berbeda
nyata berdasarkan uji DMRT $(\alpha=5 \%)$

Berdasarkan tabel diatas nilai vitamin $\mathrm{C}$ terendah yaitu pada K1 dengan penambahan 0,5\% CMC sebesar 5,0 $\mathrm{mg} / 100 \mathrm{~g}$, sedangkan hasil tertinggi yaitu pada K3 dengan penambahan $1 \%$ CMC sebesar 5,9 mg/100g. (Harahap et al., 2020). CMC (Carboxy Methyl Cellulose) yaitu suatu zat padat jenis ester selullosa, turunan dari selulosa yang sering dipakai dalam industri makanan untuk memperbaiki atau mendapatkan tekstur yang baik. Hasil vitamin C produk jadi memiliki nilai lebih kecil daripada nilai ekstrak murni karena vitamin C mudah rusak terkena panas, dan oksidasi (Pakaya, 2014).

\section{Antosianin}

Berdasarkan hasil analisa sidik ragam perlakuan penambahan sari bayam dan konsentrasi CMC tidak berpengaruh nyata terhadap kadar antosianin. Perlakuan penambahan sari bayam berpengaruh nyata serta konsentrasi CMC tidak berpengaruh nyata terhadap kadar antosianin. 
Tabel 4. Nilai Antosianin Velva dengan Penambahan Sari Bayam Merah

\begin{tabular}{ll}
\hline Perlakuan & Total Antosianin (mg/L) \\
\hline B2 (Sari Bayam 25\%) & $0,915^{\mathrm{a}}$ \\
B3 (Sari Bayam 30\%) & $1,168^{\mathrm{a}}$ \\
\hline B0 (Produk Pasar) & 95,935 \\
\hline
\end{tabular}

Keterangan : Angka-angka yang diikuti oleh huruf kecil yang berbeda menunjukkan berbeda nyata berdasarkan uji DMRT $(\alpha=5 \%)$

Berdasarkan hasil analisa ragam menunjukkan bahwa perlakuan B2 (Sari Bayam 25\%) tidak berbeda nyata dengan B3 (Sari Bayam 30\%). Hasil total antosianin produk pasaran lebih besar dikarenakan produk berbahan dasar buah stroberi. Kandungan antosianin pada tanaman dipengaruhi oleh beberapa faktor yaitu cahaya, suhu, dan $\mathrm{pH}$. Antosianin stabil pada $\mathrm{pH} 3-5$ dan suhu $50^{\circ} \mathrm{C}$, dan dalam penyimpanan $\pm 4^{\circ} \mathrm{C}$ (Hidayah, 2013).

Analisis scanning panjang gelombang antosianin bayam merah menghasilkan absorbansi $\AA$ maksimum terdapat pada panjang gelombang 223 $\mathrm{nm}$ dan $227 \mathrm{~nm}$ dengan disebutkan senyawa yang terkandung dalam bayam merah yaitu glikon. Panjang gelombang maksimal antosianin bayam merah yaitu $536 \mathrm{~nm}$ dengan absorbansi pigmen pekat 0,315 (Saati, 2015). Nilai panjang gelombang antosianin pada UV-Vis yaitu $536 \mathrm{~nm}$ yang merupakan senyawa antosianin berjenis sianidin (Adam, 2017). Penelitian sebelumnya melaporkan ekstrak etanol daun bayam merah mengandung senyawa golongan flavonoid, fenolik, dan saponin serta tidak mengandung glikosida (glikon) (Ningsih et al., 2019). Antosianin dalam bentuk aglikon (bukan gula) lebih aktif daripada bentuk glikosidanya. Perbedaan kandungan ini dikarenakan sumber bayam merah yang digunakan peneliti berbeda. Perbedaan asal tanaman dapat mempengaruhi kandungan senyawa kimia karena perbedaan tanah, kandungan air, lingkungan, dan iklim (Salim, 2018).

\section{Aktivitas Antioksidan}

Berdasarkan hasil analisis ragam menunjukkan bahwa tidak ada interaksi namun, perlakuan penambahan sari bayam berpengaruh sangat nyata, sedangkan penambahan konsentrasi CMC tidak berpengaruh nyata terhadap nilai antioksidan Velva.

Tabel 5. Nilai Rerata Aktivitas Antioksidan Velva dengan Penambahan Sari Bayam Merah

\begin{tabular}{ll}
\hline Perlakuan & Aktivitas Antioksidan (\%) \\
\hline B1 (Sari Bayam Merah 20\%) & $43,87^{\mathrm{a}}$ \\
B2 (Sari Bayam Merah 25\%) & $53,64^{\mathrm{b}}$ \\
B3 (Sari Bayam Merah 30\%) & $59,70^{\mathrm{c}}$ \\
\hline Kontrol (Produk Pasar) & 83,43 \\
\hline
\end{tabular}

Keterangan : Angka-angka yang diikuti oleh huruf kecil yang berbeda menunjukkan berbeda nyata berdasarkan uji DMRT $(\alpha=5 \%)$ 
Berdasarkan hasil analisa ragam menunjukkan bahwa perlakuan B1 (sari bayam merah 20\%), B2 (sari bayam merah 25\%), dan B3 (sari bayam merah $30 \%)$ saling berbeda nyata satu sama lain. Nilai terendah yaitu pada B1 dengan penambahan sari sebanyak $20 \%$ dengan nilai $43,86 \%$ dan nilai tertinggi terdapat perlakuan B3 dengan penambahan sari $30 \%$ dengan nilai 59,7\%. Hal ini menunjukkan bahwa semakin banyak penambahan ekstrak bayam juga meningkatkan kadar aktivitas antioksidan yang membuktikan bahwa kandungan sumber antioksidan dari bayam merah yang semakin bertambah. Sari daun bayam merah memiliki potensial aktivitas antioksidan yang sangat kuat yaitu mempunyai nilai $\mathrm{IC}_{50} 4,32 \mu \mathrm{g} / \mathrm{ml}$ (Syaifuddin, 2015). Berdasarkan hasil histogram diatas nilai aktivitas antioksidan semakin tinggi sesuai dengan perlakuan penambahan ekstrak bayam. Hal ini dikarenakan CMC sebagai bahan penstabil akan terdispresi, dalam ai $_{53,7}$, kemudian butir-butir CMC yang bersifat hidrơ $\mathfrak{f}_{\text {flik }}$ akan menyerap air dan terjadi pembengkakan. Menurut Semakin bes: ekstrak dalangel akan stabil dan nilai aktivitas antioksidan pun akan semakin meningkat (Ǩ

\section{Viskositas}

Berdasarkan hasil analisa ragam perlakuan penambahan ekstrak bayam dan konsentrasi CMC terhadap Velva tidak berpengaruh nyata. Penambahan konsentrasi CMC tidak berpengaruh nyata sedangkan penambahan konsentrasi CMC berpengaruh nyata terhadap nilai viskositas Velva.

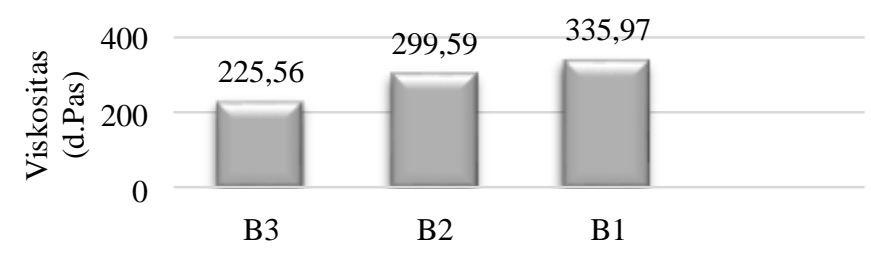

Gambar 1. Histogram Nilai Viskositas Velva Bayam Merah dengan Penambahan Ekstrak Bayam Merah

Nilai viskositas suatu bahan tinggi maka viskositas bahan semakin kental, begitu sebaliknya jika nilai viskositas rendah maka suatu bahan tersebut semakin cair. Berdasarkan histogram diatas nilai viskositas terendah yaitu B3 dengan konsentrasi sari bayam 30\% sedangkan nilai tertinggi yaitu pada B1 dengan konsentrasi sari bayam $20 \%$.

Tabel 6. Nilai Viskositas Velva Bayam Merah dengan Penambahan Konsentrasi

\begin{tabular}{ll} 
CMC & \\
\hline Perlakuan & Viskositas (d.Pas) \\
\hline K1 (CMC 0,5\%) & $117,77^{\mathrm{a}}$ \\
K2 (CMC 0,75\%) & $292,50^{\mathrm{ab}}$ \\
K3 (CMC 1\%) & $450,83^{\mathrm{b}}$ \\
\hline K0 (Produk Pasar) & 697,45 \\
\hline
\end{tabular}


Keterangan : Angka-angka yang diikuti oleh huruf kecil yang berbeda menunjukkan berbeda nyata berdasarkan uji DMRT $(a=5 \%)$

Berdasarkan hasil analisa ragam menunjukkan bahwa perlakuan K1 (CMC 0,5\%), K2 (CMC 0,75\%), dan K3 (CMC 1\%) saling berbeda nyata satu sama lain. Nilai terkecil yaitu pada perlakuan K1 dengan penambahan CMC 0,5\% sebesar 117,77 d.Pas sedangkan nilai tertinggi yaitu pada K3 dengan penambahan CMC 1\% sebesar 450,83 d.Pas. Hal ini menunjukkan semakin banyak penambahan bahan penstabil yaitu CMC akan semakin tinggi nilai viskositasnya. Hidrokoloid merupakan zat yang larut dalam air, memiliki molekul yang tinggi dan polisakarida yang berat selain itu memiliki fungsi dalam sistem makanan seperti meningkatkan viskositas, membentuk gel, mengontrol kristalisasi, menghambat sineresis, memperbaiki tekstur, dan lainlain (Burey et al., 2008).

\section{Daya Leleh}

Berdasarkan hasil analisa ragam perlakuan penambahan sari bayam merah dan konsentrasi CMC tidak berpengaruh nyata terhadap daya leleh Velva. Penambahan sari bayam merah tidak berpengaruh sedangkan konsentrasi CMC berpengaruh nyata terhadap daya leleh Velva.

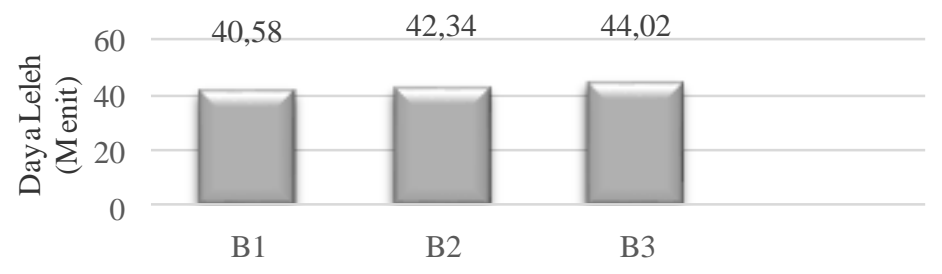

Gambar 2. Histogram Nilai Daya Leleh Velva Bayam Merah dengan Penambahan Ekstrak Bayam Merah

Berdasarkan grafik dapat disimpulkan semakin banyak penambahan sari bayam merah semakin tinggi daya leleh Velva. Menurut Haryanti (2015), menyatakan kualitas es krim yang baik untuk meleleh dalam 10 gram es krim sebesar 15-20 menit pada suhu ruang. Hal ini menunjukkan bahwa penambahan sari bayam merah mampu memberikan waktu pelelehan yang cukup baik.

Tabel 7. Nilai Daya Leleh Velva Bayam Merah dengan Penambahan CMC

\begin{tabular}{ll}
\hline Perlakuan & Daya Leleh (menit) \\
\hline K1 (CMC 0,5\%) & $35,44^{\mathrm{a}}$ \\
K2 (CMC 0,75\%) & $40,90^{\mathrm{a}}$ \\
K3 (CMC 1\%) & $50,63^{\mathrm{b}}$ \\
\hline Kontrol (Produk Pasar) & 58,30
\end{tabular}

Keterangan : Angka-angka yang diikuti oleh huruf kecil yang berbeda menunjukkan berbeda nyata berdasarkan uji DMRT $(\alpha=5 \%)$

Tabel diatas menunjukkan waktu leleh tercepat yaitu K1 dengan nilai 35,44 menit, sedangkan waktu terlama yaitu 50,63 menit pada perlakuan K3. 
Hasil analisa menunjukkan semakin banyak konsentrasi CMC yang ditambahkan semakin lama waktu leleh Velva. Hal ini dikarenakan CMC larut dalam air dan bersifat hidrofilik. Bahan penstabil dalam Velva berfungsi untuk memperbaiki tekstur dan memperlambat laju pelelehan. CMC memiliki kemampuan mengikat air, molekul-molekul air yang terperangkap dalam tekstur gel sehingga es krim tidak cepat meleleh (Burey et al., 2008). Penambahan bahan penstabil dengan presentase yang banyak akan membuat adonan lebih kental sehingga memperlambat resistensi pelelehan (Waliyurahman et al., 2019).

\section{Analisa Organoleptik Velva Bayam Merah Warna}

Berdasarkan analisis ragam perlakuan penambahan sari bayam merah dan konsentrasi CMC tidak berpengaruh nyata terhadap hasil organoleptik warna Velva. Perlakuan penambahan sari bayam merah tidak berpengaruh nyata dan penambahan konsentrasi CMC juga tidak berpengaruh nyata.

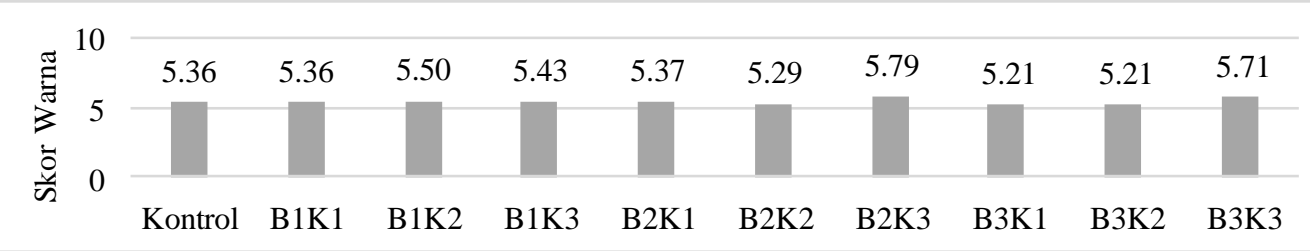

Gambar 3. Histogram Nilai Organoleptik Warna dengan Penambahan Sari

Bayam Merah

Keterangan :

Kontrol $=$ Produk Pasar

$\mathrm{B} 1=$ Sari Bayam 20\%; B2 = Sari Bayam 25\%; B3 = Sari Bayam 30\%

$\mathrm{K} 1=\mathrm{CMC} 0,5 \% ; \mathrm{K} 2=\mathrm{CMC} 0,75 \% ; \mathrm{K} 3=\mathrm{CMC} 1 \%$

Skor : $1=$ Sangat tidak menarik, $2=$ Tidak menarik, $3=$ Agak tidak menarik, $4=$ Netral, $5=$ Agak menarik, $6=$ Menarik, 7 = Sangat menarik.

Rerata hasil organoleptik warna menunjukkan angka 5 yang mempunyai keterangan agak menarik. Perbedaan hasil penilaian Velva disebabkan karena adanya kecenderungan secara tidak rerata yang berbeda pada setiap perlakuan yang menyebabkan tingkat kesukaan warna yang berbeda antar panelis. Faktor yang menyebabkan bahan pangan mengalami perubahan warna yaitu akibat proses pembuatan, pengaruh panas terhadap bahan yang ditambahkan atau secara alami terdapat pada bahan pangan itu sendiri (Winarno, 2019).

\section{Aroma}

Berdasarkan hasil analisa ragam perlakuan penambahan sari bayam merah dan konsentrasi CMC berpengaruh nyata terhadap aroma Velva. Skor aroma tertinggi produk yaitu pada B1K1 dengan skor 5,50. sedangkan skor terendah yaitu B3K2 dengan skor 4,21. Hasil pengamatan menunjukkan bahwa perlakuan penambahan sari bayam merah dengan konsentrasi berbeda memberikan pengaruh terhadap aroma Velva. Semakin banyak bayam merah yang ditambahkan cenderung semakin rendah tingkat kesukaan panelis 
terhadap aroma yoghurt bayam merah (Handayani et al., 2017). Aroma bayam merah sedikit agak langu jika di proses atau diolah menjadi produk. Enzim lipoksidase terdapat pada sayuran dengan menghidrolisis atau mengurangi lemak menjadi senyawa-senyawa penyebab langu yang tergolong pada kelompok heksanal 7 dan heksanol. Aroma langu pada sayuran dapat dikurangi dengan cara blanching ataupun steaming (Marta, 2019).

Tabel 8. Rata Nilai Organoleptik Aroma Velva Bayam Merah

\begin{tabular}{ll}
\hline Perlakuan & Nilai Aroma \\
\hline B1K1 (Sari Bayam Merah 20\%+ CMC 0,5\%) & $5,50 \mathrm{bc}$ \\
B1K2 (Sari Bayam Merah 20\%+ CMC 0,75\%) & $4,29 \mathrm{a}$ \\
B1K3 (Sari Bayam Merah 20\%+ CMC 1\%) & $4,71^{\mathrm{ab}}$ \\
B2K1 (Sari Bayam Merah 25\%+ CMC 0,5\%) & $4,57 \mathrm{ab}$ \\
B2K2 (Sari Bayam Merah 25\% + CMC 0,75\%) & $4,50 \mathrm{ab}$ \\
B2K3 (Sari Bayam Merah 25\% + CMC 1\%) & $5,00^{\mathrm{ab}}$ \\
B3K1 (Sari Bayam Merah 30\% + CMC 0,5\%) & $4,79^{\mathrm{ab}}$ \\
B3K2 (Sari Bayam Merah 30\% + CMC 0,75\%) & $4,21^{\mathrm{a}}$ \\
B3K3 (Sari Bayam Merah 30\% + CMC 1\%) & $4,79^{\mathrm{ab}}$ \\
\hline Kontrol (Produk Pasar) & 6,14 \\
\hline
\end{tabular}

Keterangan : Angka-angka yang diikuti oleh huruf kecil yang berbeda menunjukkan berbeda nyata berdasarkan uji DMRT $(\alpha=5 \%)$

\section{Rasa}

Rasa merupakan komponen penting dalam produk untuk menentukan kualitas sehingga diterima oleh masyarakat. Berdasarkan hasil analisa ragam menunjukkan tidak ada interaksi antara penambahan ekstrak bayam merah dan CMC terhadap kualitas rasa Velva bayam merah.

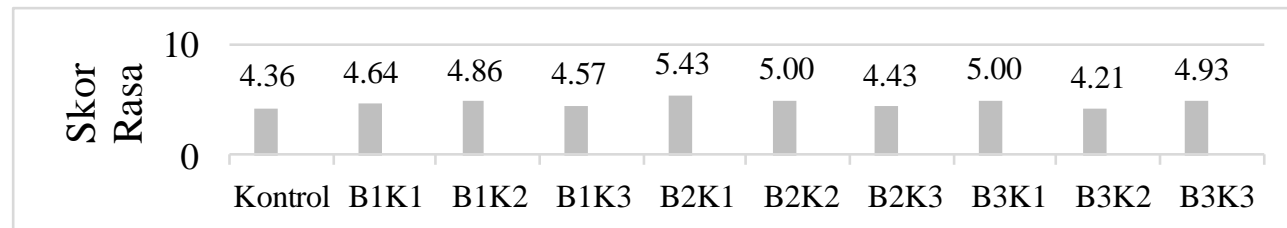

Gambar 4. Histogram nilai Rasa Velva Bayam Merah

Keterangan :

Kontrol $=$ Produk Pasar

$\mathrm{B} 1=$ Sari Bayam 20\%; B2 = Sari Bayam 25\%; B3 = Sari Bayam 30\%

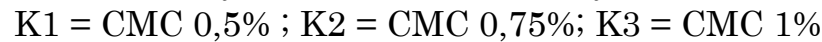

Skor : $1=$ Sangat tidak enak, $2=$ Tidak enak, $3=$ Agak tidak enak, $4=$ Netral, $5=$ Agak enak, $6=$ Enak, 7 = Sangat enak.

Berdasarkan hasil skor histogram diatas diketahui bahwa skor kesukaan panelis terhadap rasa Velva bayam merah tertinggi adalah B2K1 dengan penambahan sari bayam merah $50 \mathrm{ml}$. Bayam merah memiliki aroma yang khas seperti dedaunan sehingga sebagian panelis tidak menyukainya (Ilona,2015). Faktor lain yang menyebabkan panelis tidak menyukai rasa Velva antara lain karena kurangnya daya tarik masyarakat untuk mengkonsumsi produk daun 
bayam merah, penggunaan bayam merah di masyarakat masih rendah sehingga banyak panelis yang belum bernah mengonsumsi bayam merah.

\section{Tekstur}

Berdasarkan hasil analisa ragam menunjukkan tidak ada interaksi antara penambaan ekstrak bayam merah dan konsetrasi CMC terhadap organoleptik tekstur Velva bayam merah.

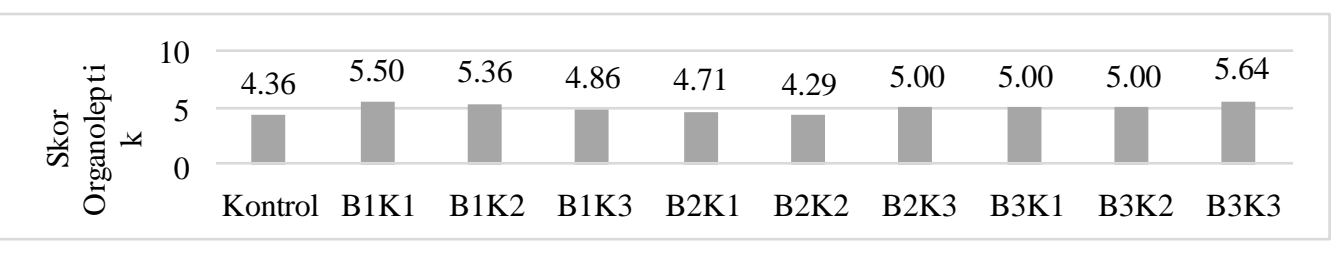

Gambar 5. Histogram Nilai Organoleptik Tekstur Velva Bayam Merah

Keterangan :

Kontrol $=$ Produk Pasar

B1 = Sari Bayam 20\%; B2 = Sari Bayam 25\%; B3 = Sari Bayam 30\%

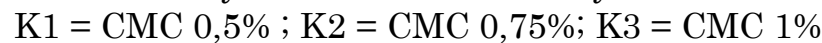

Skor : $1=$ Sangat tidak lembut, $2=$ Tidak lembut, $3=$ Agak tidak lembut, $4=$ Netral, $5=$ Agak lembut, $6=$ Lembut, 7 = Sangat lembut.

Parameter tekstur diukur saat saat berada dalam mulut merupakan penentuan kesukaan konsumen terhadap produk makanan. Perlakuan yang mendapatkan skor tertinggi yaitu B3K3 dengan penambahan sari bayam 60\% dan CMC 1\%. Karakteristik tekstur berhubungan dengan rasa pada waktu mengunyah bahan tersebut. Salah satu cara penentuan tekstur suatu produk yaitu dengan metode preference test atau uji kesukaan terhadap tekstur dalam mulut. Tekstur ideal es krim atau frozen food yaitu halus dan partikel padatan terlalu kecil untuk dapat dirasakan di mulut (Sanggur, 2017). Nilai tekstur setiap perlakuan antar panelis berbeda tergantung kesukaan panelis. Tekstur lembut dipengaruhi oleh bahan-bahan yang dicampurkan, pengolahan, dan penyimpanan (Waladi et al., 2015).

\section{Kesukaan}

Berdasarkan hasil analisa sidik ragam bahwa perlakuan penambahan sari bayam merah dan konsentrasi CMC tidak berpengaruh nyata terhadap kesukaan Velva bayam merah.

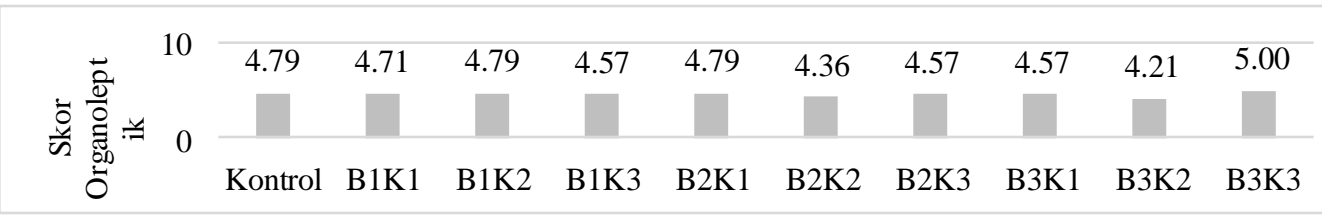

Gambar 6. Histogram Nilai Organoleptik Kesukaan Velva Bayam

Keterangan :

Kontrol $=$ Produk Pasar

$\mathrm{B} 1=$ Sari Bayam 20\%; B2 = Sari Bayam 25\%; B3 $=$ Sari Bayam $30 \%$

$\mathrm{K} 1=\mathrm{CMC} 0,5 \% ; \mathrm{K} 2=\mathrm{CMC} 0,75 \% ; \mathrm{K} 3=\mathrm{CMC} 1 \%$ 
Skor : $1=$ Sangat tidak suka, $2=$ Tidak suka, $3=$ Agak tidak suka, $4=$ Netral, $5=$ Agak suka, $6=$ Suka, 7 = Sangat suka.

Kesukaan konsumen terhadap Velva dengan penambahan sari bayam merah menunjukkan nilai 4,3-5 (netral-agak suka). Nilai tertinggi yaitu B3K3 dengan ekstrak $30 \%$ dan CMC 1\%. Nilai organoleptik kesukaan tiap-tiap panelis berbeda, rasa yang dihasilkan oleh Velva bayam merah masih terasa asing dikarenakan masyarakat masih pengenalan dan beradaptasi terhadap rasa Velva. Sedangkan warna Velva bayam merah yaitu merah keunguan dikarenakan bayam merah mengandung antosianin yang memberikan warna merah keunguan. Aroma Velva langu dikarenakan bayam merah mengandung enzim lipoksidase. Sedangkan tekstur Velva dipengaruhi oleh bahan yang dicampurkan, pengolahan, dan penyimpanan. Es krim yang tergolong baik yaitu es krim yang memiliki tekstur dan penampakan yang halus dengan cita rasa yang enak. Sedangkan es krim yang tergolong sedang yaitu es krim yang memiliki tekstur yang kurang lembut karena mengandung kristal es yang cukup banyak (Waliyurahman et al., 2019).

\section{KESIMPULAN}

Berdasarkan hasil penelitian yang telah dilakukan diperoleh beberapa kesimpulan yaitu perlakuan kombinasi penambahan ekstrak bayam merah dan konsentrasi CMC yang berbeda menunjukkan interaksi pada aktivitas antioksidan, kadar vitamin C, daya leleh, viskositas, antosianin, dan uji organoleptic Velva yang dihasilkan. Ekstrak bayam merah berpengaruh nyata terhadap antioksidan, antosianin, dan vitamin C Velva bayam merah. Penambahan ekstrak bayam merah berpengaruh nyata terhadap antioksidan dengan nilai terbesar pada perlakuan B3 (Ekstrak Bayam 30\%) sebesar 59,70\%, vitamin C tertinggi yaitu perlakuan B1 (Ekstrak Bayam 20\%) sebesar 6,3\% dan antosianin sebesar $1,167 \mathrm{mg} / \mathrm{L}$.

\section{REFRENSI}

Adam, D. H. 2017. Penentuan Antosianin dari Daun Bayam Merah (Alternanthera amoena Voss.) serta Alikasinya Sebagai Pewarna Minuman. Jurnal Pembelajaran dan Biologi Nukleus, 3, 10-16.

Burey, P., Bhandari, B., Howes, T. \& Gidley, M. 2008. Hydrocolloid gel particles: formation, characterization, and application. Critical reviews in food science and nutrition, 48, 361-377. doi: 10.1080/10408390701347801

Handayani, Z., Prasetyo, J. Y. \& Harismah, K. 2017. Uji Organoleptik dan Kadar Glukosa Yoghurt Kulit Semangka dengan Substitusi Pemanis Sukrosa dan Ekstrak Daun Stevia (Stevia rebaudiana). URECOL, 147-156.

Harahap, M., Zaenab, S. \& Waluyo, L. Pengaruh jenis apel dan konsentrasi CMC (Carboxy Methyl Cellulose) terhadap kualitas sorbet buah sebagai sumber belajar biologi. Prosiding Seminar Nasional Pendidikan Biologi, 2020. 
Hidayah, T. 2013. Uji stabilitas pigmen dan antioksidan hasil ekstraksi zat warna alami dari kulit buah naga (Hylocereus undatus). Universitas Negeri Semarang.

Kartika Dewi, R. 2012. Stabilizer concentration and sucrose to the velva tomato fruit quality. Jurnal Teknik Kimia, 4, 330-334.

Katja, D. 2019. Efek Penstabil Oksigen Singlet Ekstrak Pewarna dari Daun Bayam Terhadap Fotooksidasi Asam Linoleat, Protein dan Vitamin C. Chemistry Progress, 2.

Khristantyo, Y., Astuti, I. Y. \& Suparman, S. 2011. Profil Sifat Fisik Gel Antioksidan Ekstrak Buncis (Phaseolus vulgaris L) Dengan Basis Cmc Na. PHARMACY: Jurnal Farmasi Indonesia (Pharmaceutical Journal of Indonesia), 8.

Maria, D. N. \& Zubaidah, E. 2014. Pembuatan Velva Jambu Biji Merah Probiotik (Lactobacillus acidophilus) Kajian Persentase Penambahan Sukrosa dan Cmc [In Press Oktober 2014]. Jurnal Pangan dan Agroindustri, 2, 18-28.

Marta, N. W. V. S. 2019. Karakteristik Bakpao Berdasarkan Penambahan Ektsrak Cair Daun Kelor (Moringa oleifera). Poltekkes Denpasar.

Ningsih, D. R., Yuliani, R. \& St, M. B. 2019. Aktivitas Sitotoksik Ekstrak Etanol Daun Bayam Merah (Amaranthus gangeticus) Terhadap Sel HeLa dan WiDr. Universitas Muhammadiyah Surakarta.

Nirmalayanti, K. A. 2017. Peningkatan produksi dan mutu tanaman bayam merah (Amaranthus amoena Voss) melalui beberapa jenis pupuk pada tanah inceptisols, desa Pegok, Denpasar. JURNAL NASIONAL, 1, 1-10.

Pakaya, D. 2014. Peranan Vitamin C pada kulit. Medika Tadulako: Jurnal Ilmiah Kedokteran Fakultas Kedokteran dan Ilmu Kesehatan, 1, 45-54.

Pebrianti, C., Ainurrasjid, A. \& Purnamaningsih, S. L. 2015. Uji kadar antosianin dan hasil enam varietas tanaman bayam merah (Alternanthera amoena Voss) pada musim hujan. Jurnal Produksi Tanaman, 3.

Putri, W. C. H. 2020. Karakteristik Water Ice Bayam Merah dan Bahan Penstabil CMC (Carboxy Methyl Cellulose). Universitas Muhammadiyah Malang.

Saati, E. A. 2015. Eksplorasi Pigmen Antosianin Bahan Hayati Lokal Pengganti Rodhamin B dan Uji Efektivitasnya pada Beberapa Produk Industri/Pangan. Jurnal Gamma, 9.

Saati, E. A. 2016. Antioxidant power of rose anthocyanin pigment. ARPN Journal of Engineering and Applied Sciences, 11, 1201-1204.

Salim, R. 2018. Uji Aktivitas Antioksidan Infusa Daun Ungu Dengan Metoda DPPH (1, 1-diphenil-2-picrylhidrazil). Jurnal Katalisator, 3, 153-161. doi: $10.22216 / \mathrm{jk} . \mathrm{v} 3 \mathrm{i} 2.3372$ 
Sanggur, Y. F. 2017. Kualitas Organoleptik dan Daya Leleh Es Krim dengan Penambahan Presentase Buah Nenas (Anenas satifus) Berbeda. Skripsi. Universitas Hasanuddin Makassar.

Susilawati, E., Selifiana, N., Aligita, W., Ps, C. B. \& Fionna, E. 2018. Aktivitas Antidiabetes Ekstrak Etanol Daun Kerehau (Callicarpa longifolia Lamk.). Jurnal Kesehatan Bakti Tunas Husada: Jurnal Ilmu-ilmu Keperawatan, Analis Kesehatan dan Farmasi, 18. doi: 10.36465/jkbth.v18i2.398

Syaifuddin, S. 2015. Uji aktivitas antioksidan bayam merah (alternanthera amoena voss.) segar dan rebus dengan metode DPPH. UIN Walisongo.

Waladi, W., Johan, V. S. \& Hamzah, F. 2015. Pemanfaatan kulit buah naga merah (Hylocereus polyrhizus.) Sebagai bahan tambahan dalam pembuatan es krim. Riau University.

Waliyurahman, I., Bintoro, V. P. \& Susanti, S. 2019. Karakteristik Fisik, Kimia, serta Hedonik Velva Umbi Bengkuang dengan Penambahan Carboxyl Methyl Cellulose (CMC) sebagai Penstabil. Jurnal Teknologi Pangan, 3, 228-234. 